\title{
Prostate Health Cocktail Dietary Supplement
}

National Cancer Institute

\section{Source}

National Cancer Institute. Prostate Health Cocktail Dietary Supplement. NCI Thesaurus. Code $C 77860$.

A dietary supplement consisting of a blend of 8 natural ing redients with potential antineoplastic and chemopreventive activities. This dietary supplement contains vitamin D3 (as cholecalciferol), vitamin E (as d-alpha tocopherol), selenium (as Lselenomethionine), epigallocatechin (green tea extract), saw palmetto (berry extract), lycopene, and the isoflavonoids daidzein and genistein. This combination preparation may decrease prostate cell growth and inhibit prostate carcinogenesis. 